\title{
Features Of Vocabulary Exercises Contents In First Grade Senior High School Textbook
}

\author{
Thania Fransisca Br Saragih ${ }^{1}$, Erikson Saragih ${ }^{2}$, Rutmelina Sianipar ${ }^{3}$ \\ ${ }^{13}$ English Department, Faculty of Teaching Training, Prima University of Indonesia \\ ${ }^{2}$ Lecturer Of University Of Prima Indonesia \\ Email: thaniasaragih@yahoo.com ${ }^{1}$, erikson.saragih@unprimdn.ac.id ${ }^{2}$, \\ rutsianipar980@gmail.com ${ }^{3}$
}

\begin{abstract}
A Textbook is one of the tools used by a teacher to help them convey material to students during the learning process. The research used a qualitative study approach with an analytical research design of the contents of textbooks using the training method in the textbook. The objectives of the study are: (1) to see the contents of the Let's Learn English textbook to the 2013 curriculum was relevant. (2) To find out what kinds of new words are contact in the textbook. (3) Researching and analyzing how the practice of word forms in the textbook let's learn English. The results of this study show that content's of the Let's Learn English textbook for class $\mathrm{X}$ is very good. Researchers easily find information about vocabulary in the form of exercises. These findings show that: (1) Content textbooks is very relevant to the 2013 curriculum. (2) In analyzing the contents of textbooks, researchers find it easy to find information about new vocabulary. (3) The form of vocabulary exercises according to the material from the content Based on the researcher about the analysis of this textbook, the suggestion is that the reader does not just read the material in the text, but understands the meaning and purpose of the material so that information would received accurately.
\end{abstract}

Keywords: Textbook, vocabulary, and content analysis

Abstrak. Buku teks merupakan salah satu alat yang digunakan oleh seorang guru untuk membantu menyampaikan materi kepada siswa selama proses pembelajaran. Penelitian ini menggunakan pendekatan studi kualitatif dengan desain penelitian analitik isi buku teks menggunakan metode pelatihan dalam buku teks. Tujuan dari penelitian ini adalah: (1) untuk melihat isi buku ajar Ayo Belajar Bahasa Inggris sesuai kurikulum 2013. (2) Untuk mengetahui jenis kata baru apa yang berhubungan di buku teks. (3) Meneliti dan menganalisis bagaimana praktik bentuk kata dalam buku ajar mari belajar bahasa Inggris. Hasil penelitian ini menunjukkan bahwa konten buku ajar Ayo Belajar Bahasa Inggris kelas X sangat baik. Peneliti dengan mudah menemukan informasi tentang kosakata dalam bentuk latihan. Temuan ini menunjukkan bahwa: (1) Isi buku teks sangat relevan dengan kurikulum 2013. (2) Dalam menganalisis isi buku teks, peneliti mudah mencari informasi tentang kosakata baru. (3) Bentuk latihan kosakata yang sesuai dengan materi dari isiBerdasarkan penelitian peneliti tentang analisis buku ajar ini, disarankan agar pembaca tidak hanya membaca materi yang ada di teks, tetapi memahami arti dan tujuan dari teks tersebut. materi sehingga informasi akan diterima secara akurat.

\section{INTRODUCTION}

Learning vocabulary is not only learning what the vocabulary means, but also understanding what the word means and how to convey it correctly so that when we convey the information we convey it would be understood properly.

As we all know that knowledge of vocabulary is not something that we can instantly master. The vocabulary that we understand is vocabulary that we may have studied for a long time, such as when we understood vocabulary when we were in elementary school, then until adulthood the meaning of the vocabulary has not changed. Let's take a look at what (Adger, 2002) says that states that, "Vocabulary is not only confined to the meaning of words but also includes how vocabulary in language is structure". According to (Graves, 2006) Wikis have much potential in the teaching of vocabulary. Therefore, students can follow the different methods in learning vocabulary:

1. Students should supply the information included the context and the meaning.

2. Students would be engaged and should have given enough time to learn the word.

3. Students should have many disclosures by practicing and reviewing the word.

4. Students would have conversation about the meaning of the word.

Teaching and learning vocabulary is an important part of the classroom and in 
teaching. We will therefore briefly list three aspects that are relevant in vocabulary acquisition and learning: (i) vocabulary acquisition from a cognitive perspective, that is, as conditioned by the processes our brain has to follow; (ii) the role of frequency in vocabulary acquisition or learning and how this questioning affects the textbook, and (iii) the distribute of vocabulary would be studied throughout the textbook. The words would be studied must pay attention to the learning situation. This requires newness in exposure, words being introduced gradually and gradually, and at the same time as before presented and learned would be reintroduced later to support repetition.

Teaching techniques for adult and novice learners are very different. A teacher must really understand the situation and condition of his students. According to (Harris, 1969) there are several methods in the English learning process they are (a) Giving total physical activity (example games and total physical response activity). (b) Providing hands on activities (example to three learn words, sentences, and practice meaningful language), (c) Internalizing the concept through visual aids (example video, picture, tapes, music, flash card, and puppet toys), and (d) Explaining things with nonverbal language (facial features, gestures) will fail.

Textbook is one of the materials that is often used in teaching and learning activities. Textbooks are also a source of knowledge that is easy to get and can help students get learning material (Widianingsih, 2009 ) nevertheless, points out that vocabulary mastery would be the first priority in English language teaching and learning. Textbooks can also cover a variety of materials would be taught. On the other hand, textbooks also support the learning process regularly and effectively, without textbooks teaching and learning activities will not run smoothly and effectively.

In educational activities in Indonesia, textbooks are a major part of learning tailored to the existing curriculum. In educational activities in Indonesia, textbooks was preparing by authorities based on the latest curriculum. According to (D, 2003) textbooks are vitally important, they play a significant role in shaping teachers', students' and families' views of school subjects. Textbooks would be defined simply as books which for teaching and / or learning. According to (Tomlinson, 2011), "textbook is the one of tools that used to help teachers to teach the learners".

The textbook should also have qualities by the material would be taught. The qualities from the textbook can also be seen from the aspects of the content, presentation, graphics, and linguistic aspects of the textbook. Existing material should also be by the curriculum and be equipped with attractive illustrations, so that students interesting and can more easily understand the subject. Do not escape the use of words from the material presentation so that it is not monotonous and developed according to the student's school level.

Currently, various types of textbooks have been publish to meet the needs. (Awasthi, 2006) offers more detail definition, saying that "textbook is a teaching and learning material for both the teachers and the learners to rely on the process of teaching and learning" students in learning activities. Therefore, the task of a teacher is to choose a book to guide students. In addition to book choice, teachers must also understand that curriculum is the main source of teachers in knowing competency standards, basic competencies, learning materials, learning activities, indicators and time allocation.

The benefit of this textbook analysis is to help the reader understand what the intent and purpose of each learning material is. Here the writer describes what is analyze before knowing what kind of vocabulary to study. In addition, the researcher hopes that with the analysis of this textbook, it can improve critical thinking so that understanding in reading textbooks can increase. Textbooks also have an important role for students or teachers, but (E, A, \& R, 2004) provide a basic outline for the role of textbook intermediaries: 
1. To teach and encourage students to construct new knowledge

2. To balance detail and precision of information

3. To provide logical and consistent mathematical systems

4. To bring about new questions

5. To provide students with active, creative, many sided information

\section{Research Questions}

The study aims to discuss the research question: The question was address by the following sub-questions.

1. What types of vocabulary contents that has been stated in "Let's Learn English "Textbook for Senior High School students in First Grade?

2. How are vocabulary exercise contents represented in "Let's Learn English "Textbook for Senior High School students in First Grade?

3. Have the vocabulary material contents been relevant to 2013 English Curriculum for Senior High School.

\section{The Objective of the Study}

Based on the problems research questions above, the objectives of this study are:

1. To describe the types of vocabulary exercises stated in "Let's Learn English " Textbook for Senior High School students in First Grade.

2. To describe vocabulary exercise contents represented in "Let's Learn English" Textbook for Senior High School students in First Grade.

3. To describe how relevance vocabulary exercise contents to 2013 English Curriculum for Secondary School level.

\section{The Scope and Limitation of the Study}

This study exercise contents was limit to analyze the vocabulary on the English textbook entitled "Let's Learn English" that is use in the first level of high school. Which published by PT. Bumi Aksara in 2014 with the 2013 curriculum with the 2016 revised edition written by Drs. H. Sophia Fanany, M. Pd and Dra. Aisyah Anwar, M. Pd. In this study, the data obtained or obtained came from the textbook "Let's Learn English", which is in the form of vocabulary content where the vocabulary content is like what was present in the textbook and determines what vocabulary exercises are like in the textbook and whether it is in suitable with the 2013 curriculum.

\section{Significance of the Study}

This study is necessary for the following reasons:

1. To improve the mindset critical to study analysis.

2. Get to know new vocabulary with some of the exercises in the textbook.

3. Increase understanding of the meaning of new vocabulary that has been analyzed.

Learning vocabulary does not mean only understanding what the word means, but also understanding when and its application in different contexts. Therefore, vocabulary is the key to communication. A leading linguist (P, 2001) notes: "Vocabulary is not an end in itself. A rich vocabulary makes the skills of listening, speaking, reading, and writing easier to perform."

Knowledge of vocabulary is very important in various aspects such as in reading, writing, listening and speaking. Without vocabulary, no information would be conveyed, and vice versa, if there is no sufficient knowledge of vocabulary, there will be little understanding about information. (P, 2001) further describes the relationship between vocabulary knowledge and language use as complementary: knowledge of vocabulary enables language use and, conversely, language use leads to an increase in vocabulary knowledge. The more new vocabulary you know, the more you can learn. When you discover new vocabulary, remember them and develop them into new sentences.

\section{METHOD}

In this research design, researchers used a qualitative research approach. The data collection method uses descriptive method because in this textbook the researcher focuses more on the exercise feature of adding new vocabulary. Qualitative method is the most effective method used in the research process because the method of writing this 
report focuses on the description system. The purpose of using qualitative methods is not only to describe research in textbooks but to study and analyze in detail what problems you would like to solve properly using an analytical design.

\section{Object of the Study}

The object of research in this journal is an English book entitled "Let's Learn English" by Sophian Funnyand Aisyah Anwar publishe $\mathrm{d}$ in 2014 by PT. Bumi Aksara, and is use as a guide by teachers for teaching in schools. The reason this book is use as the object of research is because this textbook meets the criteria of researchers, namely the 2013 revised edition of the 2016 curriculum textbook which has various material reviews that can improve students' skills in the field of English. There are still many students or other readers who do not understand how to use different types of vocabulary in different contexts. So the problem analyzed in this textbook is the vocabulary training feature of each chapter has a different vocabulary difficulty level.

\section{The Instruments}

The research instrument is a research tool used by researchers so that the research aims would be accomplished. The instrument in this study is using content analysis exercises in "Let's Learn English " textbook. In a qualitative research, the researcher must understand the instruments in a study. Researchers must also know the methods used and what research problem with the right instrument, the research would carry out. Instrument in data collection was call a checklist. The data based on the existing textbook will be collect and obtained. The checklist used in this study is Vocabulary Exercises found in the textbook "Let's Learn English".

There are 8 topics on Vocabulary Exercises contained in the textbook "Let's Learn English" which is that used in the first grade of high school

Table 2.1 The of vocabulary contents exercises in the textbook "Let's Learn English"

\begin{tabular}{|l|l|l|}
\hline CHAPTER & TITLE & Vocabulary \\
\hline
\end{tabular}

\begin{tabular}{|c|c|c|}
\hline & & $\begin{array}{l}\text { Contents } \\
\text { Exercises }\end{array}$ \\
\hline Chapter I & $\begin{array}{l}\text { I'm From } \\
\text { Brazil }\end{array}$ & $\begin{array}{l}\text { Using } \\
\text { Expressions of } \\
\text { Introduction }\end{array}$ \\
\hline Chapter II & Attention! & $\begin{array}{l}\text { Finding New } \\
\text { Vocabulary }\end{array}$ \\
\hline Chapter III & $\begin{array}{l}\text { Would You } \\
\text { Like To Join } \\
\text { Me? }\end{array}$ & $\begin{array}{l}\text { Using } \\
\text { Expressions of } \\
\text { Inviting, } \\
\text { Offering }\end{array}$ \\
\hline Chapter VI & Farming & $\begin{array}{l}\text { Fill In The } \\
\text { Blanks With } \\
\text { The Suitable } \\
\text { Words }\end{array}$ \\
\hline Chapter V & $\begin{array}{l}\text { Moving to } \\
\text { the Moon }\end{array}$ & $\begin{array}{l}\text { Complete The } \\
\text { Missing Words }\end{array}$ \\
\hline Chapter VI & $\begin{array}{l}\text { Indonesian } \\
\text { Legend } \\
\text { Stories }\end{array}$ & $\begin{array}{l}\text { Find Some } \\
\text { Legend Stories }\end{array}$ \\
\hline $\begin{array}{l}\text { Chapter } \\
\text { VII }\end{array}$ & $\begin{array}{l}\text { That's } \\
\text { Surprising ! }\end{array}$ & $\begin{array}{l}\text { Match The } \\
\text { Words }\end{array}$ \\
\hline $\begin{array}{l}\text { Chapter } \\
\text { VIII }\end{array}$ & $\begin{array}{l}\text { Ahead by a } \\
\text { Century }\end{array}$ & $\begin{array}{l}\text { Fill In The } \\
\text { Blanks With } \\
\text { This, That, } \\
\text { These, or Those }\end{array}$ \\
\hline
\end{tabular}

Based on the table above, there are 8 vocabulary exercises that are present in the textbook "Let's Learn English".

\section{The Procedures of Collecting Data}

To obtain data in answering the research questions, the following steps are used in this research.

1. The author chooses an English textbook entitled "Let's Learn English"

2. The author studies vocabulary content and vocabulary exercises contained in textbooks.

3. The author analyzes each vocabulary feature exercise contained in the textbook.

\section{The Procedures of Analyzing Data}

To analyze the data obtained from the "Let's Learn English" textbook for Senior High School Students in First Grade, the researcher took the following steps:

1. Researchers read the content "Let's Learn English" textbook to identify vocabulary exercises in the textbook. 
2. Researchers try to analyze and understand what the meaning of vocabulary exercises in the textbook.

3. After knowing what kind of vocabulary to analyze, the researcher continued the case study by completing the exercises contained in the textbook.

\section{The Credibility of Data}

The analysis of this textbook uses a qualitative method where the researcher tries to present, explain, and measure the correctness of the data from various references. To find out how well the data in the study were, the researchers used a credibility test with triangulation theory which in the data involved various perspectives.

\section{FINDINGS AND DISCUSSION}

The research data are various vocabulary exercises in "Let's Learn English" textbook. There are three vocabulary exercises, completing, matching, and finding the meaning of words. The themes of vocabulary exercises is qualitative data. Qualitative data taken from observations in several chapters of textbooks as a research approach to finding information about book analysis in the form of vocabulary exercises. In studying the data, this research conducted from first grade high school textbooks.

\section{Data Analysis}

\section{Analysis of Qualitative Data}

Qualitative data taken from observation in several chapters of textbooks as a research approach to finding information about book analysis in the form of vocabulary exercises. The forms of vocabulary exercises are completing, matching, and finding the meaning of words. Completing would be found in chapters $1,4,5$, and 8 , namely in the form of completing dialogues or sentences. While the vocabulary matching exercise is in chapter 7, namely matching words from column A to B. From the analysis, it is found that vocabulary material is relevant to the 2013 high school curriculum and included in the very good category. The evidence would be seen in the findings section.
Findings The types of vocabulary contents in "Let's Learn English" textbook for Senior High School students in First Grade

The graph below shows the different types of English vocabulary and the situations where they might find them. The types of vocabulary are shown vertically on the left and the situations where they are used are shown horizontally at the bottom:

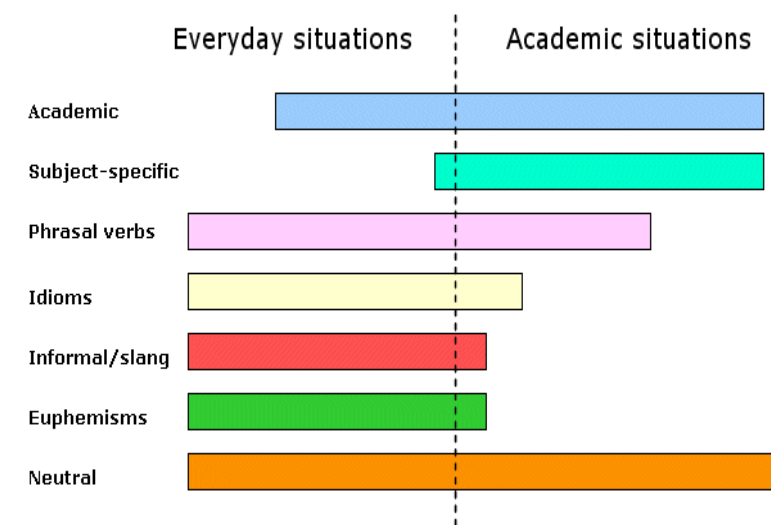

Knowledge of vocabulary are classifications based on vertical and horizontal charts. The first on Academic; here the researcher analyzes that new vocabulary is found more in academic institutions because a person's academic situation can further expand his vocabulary knowledge with various sources. Similar to everyday situations, we can also find vocabulary from our daily lives, such as by chatting with friends, watching TV shows, and reading fiction books.

However, the new vocabulary content is clearly different from the Academic situation which uses various learning resources. Second based on the subjectspecific, which in the graphics that has shown more dominant in the academic situation. Example is Moraine who focuses on geographic issues. Then the third is phrasal verbs, which are vocabulary knowledge formed from two or three words from different grammatical categories. For example to get at, to sit on, and to get into. The fourth is idioms. Idioms are sentences that cannot be interpreted literally, which means that we cannot interpret directly what the sentence means in our own sense. For example, to rain cats and dog, if taken literally means for rain 
cats and dogs, but the real meaning is heavy rain

The fifth is Informal / Slang, which is the language generally used by millennial children to show whatever their slang is in a certain group. Meanwhile, informally uses language which in general has been widely used in everyday life. For example "kids", here kids are a kind of informal word, because most of everyone is ready in their daily life. Meanwhile, "Cops" is the slang word for police officers. Another example is cool / awesome, which is a slang word that shows appreciation for something. The sixth is "Euphemism" which is a word which has a more subtle or polite meaning. For example, when faced with some situation that grieving, it is better to use the sentence for "to pass away" than the word for "death".

In the book "Let's Learn English" the researcher found types of vocabulary such as Listening Vocabulary, Speaking Vocabulary, Reading Vocabulary, and Writing vocabulary according to the language skills which are the reference if you want to master English. The first is Listening Vocabulary, consistent in every word conveyed by the informant. Example: The teacher uses an audio media that has material in the form of a conversation or a song which is then played to students in the classroom in order to practice listening to vocabulary in English.

Speaking Vocabulary, consistent in the use of the words used when speaking. Example: The teacher gives an assignment in the form of a dialogue between several people and students practicing in front of the classroom as well as practicing student pronunciation. The third is Reading Vocabulary, consistent with what is read. Example: Students was assigned to look for a story either folklore or news and students understand the contents of the reading and then read it in the classroom. The last is Vocabulary writing, consistent in our understanding of using vocabulary when writing. Example: students write a story either personal experience or personal bio to practice and increase the use and understanding of vocabulary in writing

\section{The vocabulary exercise contents represented in "Let's Learn English" Textbook for Senior High School students in First Grade.}

In the textbook "Let's Learn English", vocabulary exercises represented in each chapter, where there are 8 chapters. In the text book "Let's Learn English" the form of vocabulary training consists of four forms of training, namely completing vocabulary exercises found in chapters $1,3,4,5$, and 8 . The second form of exercise which is finding the meaning of vocabulary using a dictionary is in chapter 2. 6 forms of exercise, namely finding a legend story and the last one, namely matching vocabulary exercises in chapter 8 .

An example of vocabulary completing exercise is on page 67 task 16, which is completing conversations using introducing, greetings or parting vocabulary.

\section{Task 16}

1. Fadli : How is it going today,

Wildan?

Wildan

2. Roland : Good morning, Mr.

Hakim. How are you today, sir?

Mr. Hakim $\quad$ :............., How

about you, Roland?

3. Nanda : I'd like to introduce

myself to you, I'm Nanda.

Fatimah : Hi. I'm

Nice to meet you, Nanda.

Nanda

4. Rudi

Salim : Hi, I'm Salim.

Pleased to meet you, Rudi.

Rudi

5. Dodi : Hey, Rita. It has been

a long time not to see you.

Rita : Yeah. Where are youn

going?

Dodi : To my campus. There,

my bus is coming. Bye Rita, .........

Rita

Table 3.1 Material of Vocabulary Exercises in Chapter 1 about Introducing

Introducing 


\begin{tabular}{|l|ll|}
\hline- & Excuse me, \\
my name's .... & & May I \\
- & introduce \\
dow do you & & myself? \\
- & Hello, my & First, let me \\
name's .... & & introduce \\
& & myself. \\
& - & Allow me to \\
& & introduce \\
& myself. \\
\hline
\end{tabular}

Table 3.2 Material of Vocabulary Exercises in Chapter 1 about Greetings

\begin{tabular}{|c|c|}
\hline Greetings & Responses \\
\hline $\begin{array}{ll}- & \text { Hi! } \\
\text { - } & \text { Hello! } \\
\text { - } & \text { Hello there/ } \\
\text { (name)! } \\
\text { - } \quad \text { Good morning! } \\
\text { - } \quad \text { Good to see you } \\
\text { (again)! } \\
\text { - } \quad \text { How are you? } \\
\text { - } \quad \text { Long time no see! } \\
\text { (How/Very) nice } \\
\text { to see you } \\
\text { (again)! }\end{array}$ & $\begin{array}{ll}- & \text { Ok . } \\
\text { - } & \text { Not bad. } \\
\text { - } & \text { Just fine, } \\
\text { thank you. } \\
\text { - } \quad \text { I'm fine, } \\
\text { thank you. } \\
\text { - } \quad \text { Just so so. } \\
\text { - } \quad \text { Very well, } \\
\text { thank you. } \\
\text { - And } \\
\text { how're } \\
\text { you? } \\
\text { How about } \\
\text { you? } \\
\text { And you? }\end{array}$ \\
\hline
\end{tabular}

Table 3.3 Material of Vocabulary Exercises in Chapter 1 about Parting

\begin{tabular}{|c|c|}
\hline Parting & Responses \\
\hline $\begin{array}{ll} & \text { Bye/ Bye-bye } \\
- & \text { See you } \\
& \text { again. } \\
- & \text { See you later. } \\
\text { - } & \text { Take care of } \\
& \text { yourself. } \\
- & \text { Goodbye } .\end{array}$ & $\begin{array}{ll}- & \text { Bye } \\
- & \text { Hope so. } \\
- & \text { Sure thing. } \\
\text { - } & \text { You, too. } \\
\text { - } & \text { Goodbye. }\end{array}$ \\
\hline
\end{tabular}

The next example of vocabulary exercise is finding the meaning of vocabulary which students can use dictionary as a source, found on page 49 task 19.

\section{Task 19}

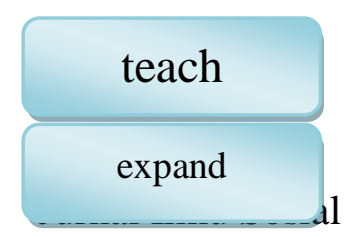

applicant

Researcher analyzes task 19 with the title "Study the words below. Use your dictionary to find out the meanings". The researcher invites the reader to find the meaning of each vocabulary by using the dictionary as a medium. not only finding the meaning of the vocabulary, but the researcher hopes that readers will also find the meaning of each word and how it is use in context.

The third form of vocabulary exercise is finding legend stories, students can use the internet, newspapers, or magazines as sources of information. Students are also expected would be able to understand the reading content of the legend because it can add new vocabulary that is not understood by students. The third vocabulary exercise form is on page 176 task 34.

The fourth example of vocabulary exercise is matching vocabulary exercises on page 189 task 15 . In this exercise students are expect would be able to match words in column A where the meaning of vocabulary in column A is in column B. This exercise is able to add new vocabulary which is rarely known by students.

The vocabulary exercises are in the form of matching words in column A where the meaning of the words is in column B. In this exercise we do not only know the new vocabulary but the meaning of the vocabulary.

The relevance of vocabulary material contents to 2013 English Curriculum for Senior High School.

The form of vocabulary material in the textbook is relevance with 2013 English Curriculum for Senior High School and falls into the very good category. Why that is relevance, because the material presentation has contained in the textbook that accordance learning activities, there are some characterized as forming traits, characters, knowledge and thinking patterns, critical and unique. In addition, why is it said would 
relevant to the 2013 curriculum because the learning process begins with observing the material first, then understanding and analyzing the material, so that students are able to complete the exercises in the textbook.

As every single $\mathrm{KI}$ and $\mathrm{KD}$ successfully implemented in the textbook, and the materials provided in the textbook completely completed as all suggested English language skills exercises of writing, speaking, reading and listening materials in the curriculum 2013 were implemented. (Harimansyah, 2008) stated that a textbook can be said to be good in content aspect, if noticed a complete reference that was accordance to the curriculum or syllabus, relevant science, and needs of learners. There are four criteria being used here. These are: The integration of four skills in learning English (reading, listening, speaking and writing) (Hendi, 2013) and as is recommended in 2013 English curriculum document (p.14). The inclusion of two main language components (grammar and vocabulary) (Hendi, 2013).

For example, it could be seen in the previous explanation where there are three examples of vocabulary exercises in the form of completing, finding legends and looking for word meanings. The form of vocabulary training with material content is very relevant, does not deviate from the material content. From the three explanations of the previous examples, it has shown that the material in the textbook "Let's Learn English" is in the very good category because it is relevant to the 2013 high school English curriculum.

\section{Discussion}

In this section, the researcher explains sequentially what is the answer to the research question:

1. What types of vocabulary contents are stated in "Let's Learn English" Textbook for Senior High School students in First Grade?

Teaching words is a crucial aspect in learning a language as languages are based on words (Thorburry, 2002) General vocabulary, there are 4 types of vocabulary that we have to learn:
The first is Listening Vocabulary, consistent in every word conveyed by the informant. Example: The teacher uses an audio media that has material in the form of a conversation or a song which is then played to students in the classroom in order to practice listening to vocabulary in English. The second is Speaking Vocabulary, consistent in the use of the words used when speaking. Example: The teacher gives an assignment in the form of a dialogue between several people and students practicing in front of the classroom as well as practicing student pronunciation The third is Reading Vocabulary, consistent with what is read. Example: Students was assigned to look for a story either folklore or news and students understand the contents of the reading and then read it in the classroom. The last is Vocabulary writing, consistent in our understanding of using vocabulary when writing. Example: students write a story either personal experience or personal bio to practice and increase the use and understanding of vocabulary in writing.

Vocabulary is also the most important part of language learning and as the meaning of new words written in a book or learning room in the classroom. On the other hand, (E \& C, 1995), indicates two kinds of vocabulary, namely receptive vocabulary and productive vocabulary. Receptive Vocabulary, receptive vocabulary is words that learners recognize and understand when they are using in context, but which they cannot produce. It is vocabulary that learners recognize when they see or meet in reading text but do not use it in speaking and writing (Webb, 2005). Productive Vocabulary, productive vocabulary is the words that the learners understand and can pronounce correctly and use constructively in speaking and writing. It involves what is needing for receptive vocabulary plus the ability to speak or write at the proper time. Therefore, productive vocabulary would be addressed as an active process, because the learners can produce the words to express their thoughts to others (Webb, 2005). 
2. How are vocabulary exercise contents represented in "Let's Learn English" Textbook for Senior High School students in First Grade?

English language skills are a musthave for someone who wants should be proficient in the field of English. These skills are divide into two parts, namely receptive skills (Listening and reading) and productive skills (Speaking and Writing). As we know that listening is an activity to understand and understand what someone is saying to us. As mentioned in (David, 2003) "Listening is an active, purposeful process of making sense of what we hear." While reading is an activity to understand what the writers said and usually readers are invite to think critically about the article. So, reading activity is not just reading briefly, but understanding what the meaning and purpose of the reading is.

(Mikulecky \& S, 2011) states that reading is a complex conscious and unconscious mental process in which the reader uses a variety of strategies to reconstruct the meaning that the author is assumed to have intended, based on data from the text and from the readers prior knowledge. On the other hand, Speaking is also called speaking activity or socializing with other people. For the sake of creating a good relationship, one must support an attitude in speaking as well.

(Nunan, 2004) stated that speaking is the productive oral skills that consist of producing systematic verbal utterance to convey meaning. When the brain has an idea, it encodes the idea and sent to the mouth by using articulation system then mouth produces the spoken text. Meanwhile, writing skills is an activity to express thoughts about something. According to (Jhon, 2012) writing is a skill and like most other skills, such as typing, driving, or cooking, it can be learned. Therefore everyone can learn writing with more practice and it can be mastered by hard work.

3. Have the vocabulary material contents been relevant to 2013 English Curriculum for Senior High School.

\section{CONCLUSION}

Based on the data, data analysis and findings in the previous chapter, the researchers conclude the followings:

1. There are 4 types of vocabulary available in the textbook entitled "Let's Learn English". The types of vocabulary are Vocabulary Reading, Vocabulary Writing, Vocabulary Listening, and Vocabulary Speaking. Because this research is base on the analysis of textbooks in the form of vocabulary exercises with the qualitative method, the researchers here are more dominant in reading and writing vocabulary in analyzing textbooks.

2. The form of vocabulary practice is well represented in the textbook entitled "Let's Learn English". This is evident from various forms of vocabulary training in textbooks: such as; (1) Using Expressions of Introduction, (2) Finding New 
Vocabulary, (3) Using Expressions of Inviting, Offering, (4) Fill In The Blanks With The Suitable Words, (5) Complete The Missing Words, (6) Find Some Legend Stories, (7) Match The Words, (8) Fill In The Blanks With This, That, These, or Those.

3. The contents of the vocabulary in the textbooks are relevant to the contents of the 2013 English curriculum. It is clearly evident from the compositions of the contents of the material according to the learning indicators, as well as the form of vocabulary exercises that are according to the contents of the material so that the research process of this textbook can run well.

\section{SUGGESTION}

Based on the conclusions in the previous chapter, the researchers suggest the followings:

1. Here the reader's inviting to think critically because in research, the researcher analyzes vocabulary exercises. If there are difficulties in finding new vocabulary, readers can use translation media such as dictionaries. Knowing the meaning of each word in the vocabulary will help us communicate with other people.

2. Researchers invite the reader's to find out how important and relevant the content in textbooks to the 2013 curriculum.

3. By conducting research on the Let's Learn English textbook, expected that it can improve qualities of learning in the present and in the future.

\section{REFERENCES}

Adger. (2002). What Teachers Need to Know about Language. London: Merril Publishing Company.

Awasthi, J. (2006). Textbook and It's Evaluation. Journal of Nelta , 1-2.

D, R. (2003). How Pressure Groups Restrict What Students Learn. New York:

Alfred A. Knopf.
E, G., A, P., \& R, L. (2004). On The Problem of Typology and Functions of School Text Copenhagen, Denmark: ICME $\mathrm{X}$.

Graves, M. F. (2006). The Vocabulary Book: Learning and Instruction.

Harris, D. P. (1969). Testing English as A Second Language. New York: Mc. Graw Hill Book Company.

P, N. I. (2001). Learning Vocabulary In Another Language. Cambridge, England.

Tomlinson, B. (2011). Materials Development in Language Teaching Second Edition. $\quad$ Cambridge: Cambridge University Press.

Widianingsih, R. (2009). Increasing vocabulary mastery using crossword puzzel technique in inclusion program. Bachelor Degree of Education .

Harimansyah. (2008). Pengembangan Model Pembelajaran: Uji Efektifitas Bahan Ajar BIPA. Jakarta: Pusat Bahasa.

Hendi, S. (2013). Bedah Curriculum 2013 Bagi Guru Bahasa Inggris . Bandung: CV Adoya MItra Sejahtera.

Jhon, L. (2012). English Skill. New York: Mc Graw Hill.

Mikulecky, \& S, B. (2011). A Short Course in Teaching Reading.

Nunan. (2004). Task Based Language Teaching. Cambridge University, 48.

S, T. (2002). How to Teach Vocabulary. England: Cambridge University Press.

Thorburry, S. (2002). How to Teach Vocabulary. England: Cambridge University Press.

Wahyuni, S. (2016). Curriculum Development Indonesia Context. ELT Journal vol 10 .

Webb, S. (2005). Recerptive and Productive Vocabulary. The Effect of Reading and Writing on Word Knowledge, Student in Second Language Acquisition, 27:33-52. 
